\title{
A New Diarylethene with Donor-acceptor Group for Reversible Photo-induced Electrochemical Switching
}

\author{
Eunkyoung Kim, Miyoung Kim, ${ }^{\dagger}$ and Kyongtae Kim ${ }^{\star}$ \\ Deparment of Chemical Engineering, Yonsei Lniversity, Seoul 120-749, Korea. ${ }^{\circ}$-mail: eunkimatonsei ackr \\ School of Chemistry and Holecular Engineering, Seoul National Lnwersity, Seoul 151-742, Korea \\ Received January 15, 2008
}

\begin{abstract}
A new diary lethene compound with donor and acceptor substituent was synthesized from 2.3-bis(2-methylbenzo[b]thiophene-3-yl)hexafluorocyclopentene (BTF) over 5 steps. The donor-acceptor structured BTF compound (TBTFE) showed spectral change to a longer wavelength through photochromism with a high cyclization quantum yield $(0.56)$. The 3.4-ethylenedioxythiophene $(T)$ and carboethoxy $(E)$ groups directly connected to BTF unit promoted electrical change accompanied with the photoisomerization of the BTF unit. Photo-induced electrical switching was achieved from a photocell containing TBTFE doped polymer film. which showed reversible and stable current change over repeated crcles by the alternative UV/Vis irradiation. as estimated by the I-V plot.
\end{abstract}

Key Words : Photochromism. Diarylethene. Ring cyclization. Ring opening. Photo-electrical switching

\section{Introduction}

Photo-induced changes of physical properties between two isomers have been collected strong interest as a tool to achieve photon mode control and molecular switching. ${ }^{1}$ Among the photon-mode control. the photochromic transformations of diarylethene between ring open and closed structure stimulated by irradiation with light at an appropriate wavelength. allow switching of electronic absorption accompanied with several important properties such as refractive index, dielectric constant and oxidation/reduction potential. $=-15$ The photochromic cyclability coloration/ bleaching cycle. of benzothiophene derivatives such as 1.2bis(2-methyl-1-benzothiophen-3-yl)perfluorocy clopentene (1. Eq. 1) could be repeated more than $10^{4}$ times while the thermally irreversible photochromic performance is kept in a solution. ${ }^{13.18}$ Such a long cyclability: thermal stability. and bi-stability ensure the application of diary lethene derivatives in organic electronics and bionics.

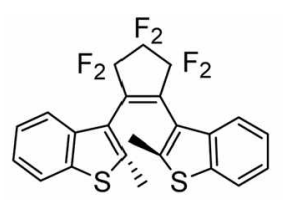

10
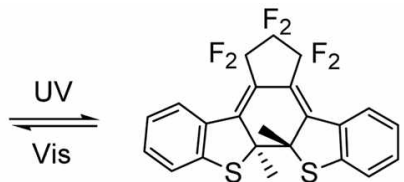

$1 c$
Importantly: the $\pi$-system of the two aryl rings is discontinued in the open-ring isomer. whereas they are connected throughout the molecule in the closed-ring isomer. Therefore. any $\pi$-electron perturbation on the two aryl rings can modify the electrical switching properties arising from the interaction of the aryl rings through the conjugated pathway. Substitution of the $6.6^{\prime}$ position on the benzothiophene ring of 1 with electron acceptor and donor group can change the $\pi$-electron density and thus. the electronic properties and electrical conductivity of diarylethene through the conjugated pathway. In particular, introduction of the electron-donating and -accepting groups to the diarylethene units could stimulate intramolecular charge transfer along the closed isomer. Although many symmetrical diarylethene compounds have been reported. ${ }^{2 ! 222}$ reports on non-sy'mmetrical derivatives and donor acceptor structures are rare.$^{23}$ Furthennore the reversibility of the photoinduced electrochemical switching of diarylethenes in solid state cell is slow. ${ }^{9 c}$ Herein we report on the synthesis and reversible photo-induced electrical switching of a new $6.6^{\prime}$ substituted non-symmetrical diarylethene. The carboethoxy (E) and 3.4-ethylene-dioxy thiophene (T) groups were substituted to the 6.6 position of 1 as a stable electron acceptor and donor, respectively.

\section{Results and Discussion}

Synthesis. 1.2-Bis(2-methyl-1-benzothiophen-3-yl)perfluorocyclopentene (1). was prepared from the reactions of perfluorocycloalkene with the organolithium compound. ${ }^{\text {s(x). Is }}$ TBTFE was synthesized in five steps from 1 with an isolations yield of $52 \%$. Monoacetylation of 1 with acetyl chloride in methylene chloride solution in the presence of aluminum chloride yielded BTFA (Scheme 1). The chemical structure of BTFA was confinned by the presence of the nonsymmetrical proton peaks in ${ }^{1} \mathrm{H}$ NMR and a strong new band at $1683 \mathrm{~cm}^{-1}$ characteristic of the carbonyl group in FTIR spectrum. Reaction of BTFA with a solution of sodium hypochlorite in 1.4-dioxane afforded BTFC that showed characteristic carbonyl group at $1691 \mathrm{~cm}^{-1}$ and a very broad $\mathrm{OH}$ band at $3400-2400 \mathrm{~cm}^{-1}$ in FT-IR spectrum. The compound IBTFC was sy'nthesized from the reaction of BTFC in acetic acid and sulfuric acid with iodine in $73 \%$ yield. After esterification of IBTFC with ethanol. IBTFE was obtained. Then TBTFE was obtained as a green powder through palla- 


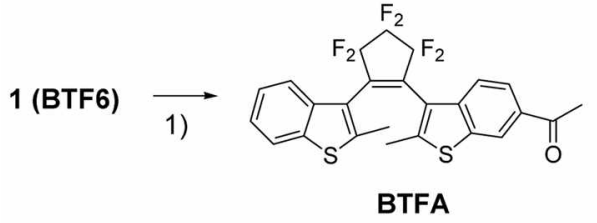

BTFA

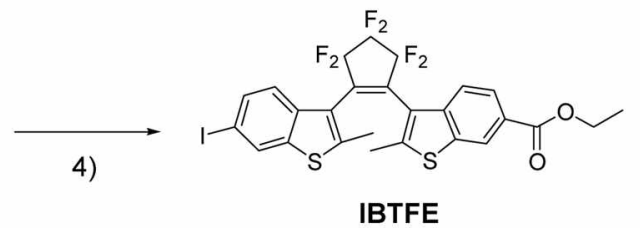

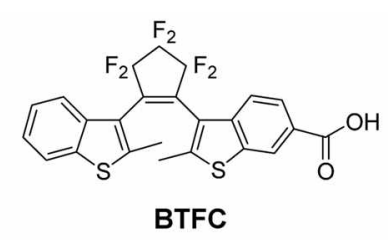

3)<smiles></smiles>

IBTFC

5) $\mathrm{PdCl}_{2}\left(\mathrm{PPh}_{3}\right)_{2} /$ toluene, retlux, 24 h.
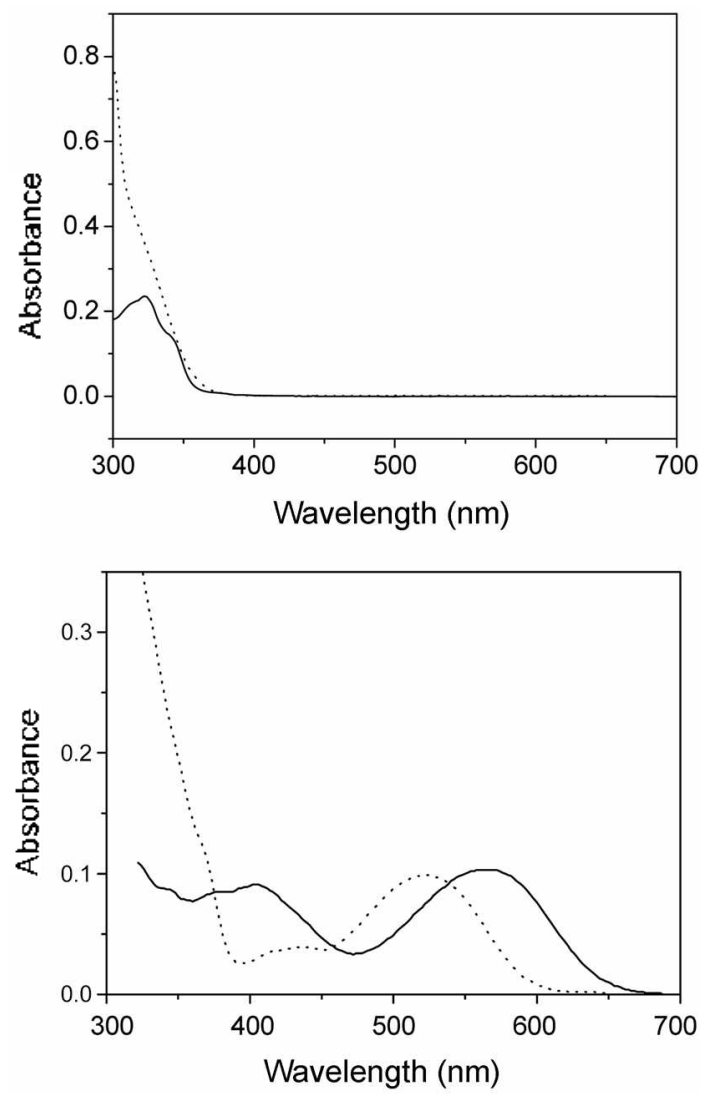

Figure 1. UV/Vis spectra of compounds $\left(1.0 \times 10^{-5} \mathrm{M}\right)$ in chloroform (a) before and (b) after irradiation with a $365 \mathrm{~mm}$ light for 2 min. for compound 1 (dotted line) and TBItE (solid line).

diunt-catalyzed Stille coupling of IBTFE with an organo tin compound $(\mathrm{TSn})^{\hat{i})}$ in the presence of a $\mathrm{Pd}\left(\mathrm{PPh}_{3}\right)_{2} \mathrm{Cl}_{2}$ catalyst. The ${ }^{\text {}} \mathrm{H}$ NMR spectrum of the unsynmetrical compounds BTFA. BTFC and TBTFE showed four different methyl protons at $\delta 2.20-2.60$, which arose from the two asymmetric aryl groups with anti-parallel and parallel structures. The ratio of the anti-parallel structure to the parallel stnucture was about $65: 35$, as determined from the peak integration. in solution.

Photochromic Properties. Figure 1 shows the UV/Vis spectral change upon the photochromic conversion of the diarylethenes in cluloroform $\left(1.0 \times 10^{-5} \mathrm{M}\right)$ through their irradiation with a $365-\mathrm{mm}$ light. Compared to the unsubstituted diarylethene (1). the absorption bands of TBTFE were red-shifted in the open (Fig. la) and closed isomer (Fig. 1b), indicating that the substituents affected the electronic transition of the diarylethene. Thus, compared to the unsubstituted diarylethene, $1 \mathrm{c}\left(\lambda_{\max }=534 \mathrm{~mm}, 2.32 \mathrm{eV}, \varepsilon\right.$ $=1 \times 10^{-4} \mathrm{~cm}^{-1} \mathrm{M}^{-1}$ ), the electronic transition of TBTFE was lowered $\sim 0.12 \mathrm{eV}$ in the closed form ( $\lambda_{\text {max }}=564 \mathrm{~nm}, 2.20$ eV. $\varepsilon=1.0 \times 10^{-4} \mathrm{~cm}^{-1} \mathrm{M}^{-1}$ ). The $\pi$-electrons could be delocalized through the electron-donating $T$ group to the electron-accepting $\mathrm{E}$ group in c-TBTFE with a pull-push structure. which led to significant spectral change. This result correlates well to the previous observation for dithienyl derivatives, the absorption maximum of which in the closed form was further shifted to low energy when a strong electron-donating and a strong electron-withdrawing dicyanoetlyylene substituent were introduced into the 5- and 5'positions of the thiophene rings. ${ }^{21}$

The quantum yields of TBTFE for ring cyclization was determined as 0.56 from the plot of the absorbance against the irradiation time ${ }^{2}$ The quantum yield was close to the maximum value based on the population ratio $(35.65)$ of the parallel to the anti-parallel conformations in TBTFE, from the ${ }^{1} \mathrm{H}-\mathrm{NMR}$ study; i.e.. almost all the photo-excited antiparallel conformations undenvent the cyclization reaction. On the other hand the quantum yields of the cycloreversion of TBTFE dramatically decreased to 0.01 . When the electron donor-acceptor groups were attached to the aryl groups. the quantum yield of the cycloreversion reaction dramatically decreased due to the significant extension of the $\pi$-conjugation throughout the diarylethene molecule. ${ }^{2-t}$ Such a long extension of the $\pi$-conjugation in the donordiarylethene-acceptor push-pull structure of TBTFE could enhance photo-induced electrochemical switching between the open and closed isomers. as described below.

Photo-induced Electrochemical Switching in the Donordiarylethene-Acceptor. As can be seen in Figure 2, there were no remarkable reduction peak in the cyclic voltammogram $(\mathrm{CV})$ for the solution of $o$-TBTFE in methylene 


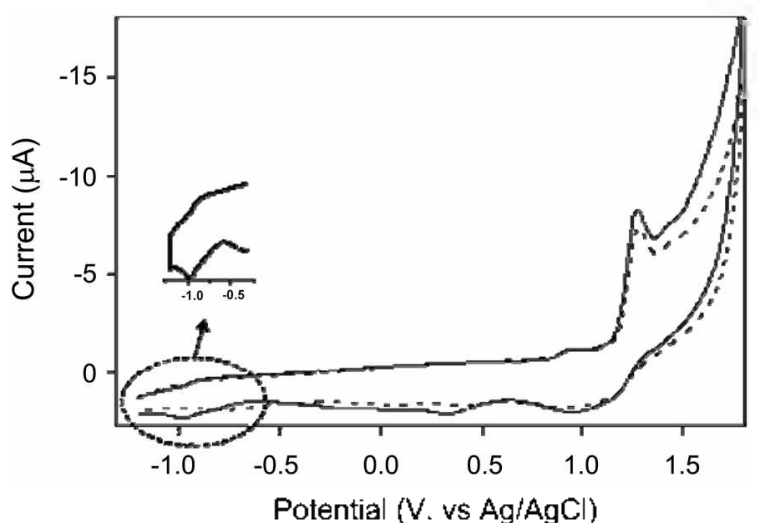

Figure 2. Cyclic voltammograms of $\operatorname{TBTFE}\left(1 \times 10^{-3} \mathrm{M}\right)$ in dichloromethane, containing $0.1 \mathrm{M}$ of $n-\mathrm{Bu}_{4} \mathrm{NClO}_{4}$ before (dashed line) and after (solid line) irradiation with 365 mon light for $2 \mathrm{~min}$.

chloride containing $0.1 \mathrm{M}$ of tetra- 7 -butylamunonium perchlorate as a supporting electrolyte, similar to that of 1. The solution of $o$-TBTFE showed oxidation peaks at $1.27 \mathrm{~V}$ and $>1.5 \mathrm{~V}$. In the literature, the oxidation potentials of thiophene-containing molecules are reported as 0.8-1.6 $\mathrm{V}^{30}{ }^{30.9 y}$ Thus, the CV waves of $o$-TBTFE at $1.27 \mathrm{~V}$ can be considered as one-electron oxidation of diarylethene containing thiophene unit.

Interestingly. the $\mathrm{CV}$ of the solution after UV irradiation showed a significant current increase above $1.3 \mathrm{~V}$ plus a new additional redox peak at $-0.91 \mathrm{~V}$ (reversible). It has been reported that the open-ring isomer of $\mathbf{1}$ does not show redox peaks in the potential range at $-1.5 \sim+1.5 \mathrm{~V}$. although the closed-ring isomer shows quasi-reversible redox potentials at -1.33 and $+1.05 \mathrm{~V}^{13.35}$ Thus. the new peak at $-0.91 \mathrm{~V}$ in $\mathrm{CV}$ could be ascribed to the reduction process of diarylethene containing the $E$ group. The reduction peak shifted towards a positive potential. thus lowering the energy for the reduction processes, possibly due to the electron-withdrawing E group. ${ }^{31}$ The small irreversible peak at $0.4 \mathrm{~V}$ could be originated from the reduction of two-electron oxidation product(s) of the closed form according to the ECE mechanism. ${ }^{2 s}$ Furthermore, the significant current increase in the potential range above $1.3 \mathrm{~V}$ from the ring closure reaction indicates that the electron transport becomes facile in the closed form. Such an electrochemical property change from the closed and open form could be utilized to the photon mode electrical switching. which can be investigated using current-voltage (I-V) characteristic measurement of a photocell containing diarylethenes.

A photocell was fabricated with three layers of $\mathrm{Au} / \mathrm{PC} /$ ITO glass. in which 'PC' represents the photochromic layer of TBTFE dispersed in a poly styrene binder (Fig. 3). The PC layer was prepared from the solution of TBTFE (10 wt \%) and polystyrene in a mixture of chloroform and trichloroethene $(3: 1, w t / w t)$. The cathode layer (Au) was in tum deposited on the photochromic film using the thermal evaporation method under the pressure of $3 \times 10^{-6}$ Torr. The thickness of the All layer and the photochronic layer were $40 \mathrm{~nm}$ and $220 \mathrm{~nm}$. respectively, with an active area of 0.02

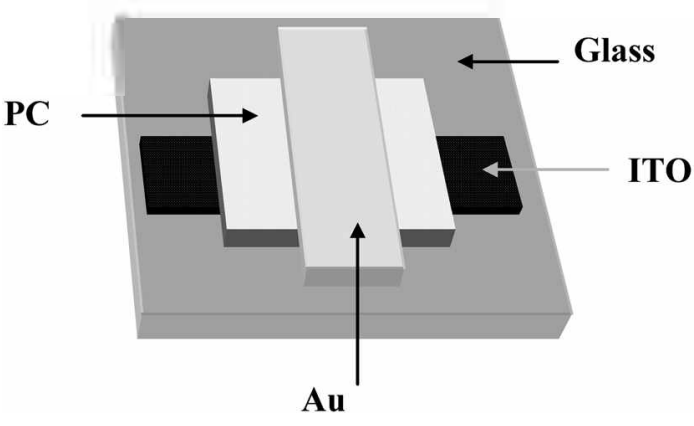

Figure 3. Structure of a photocell for the measurement of I-V curve.
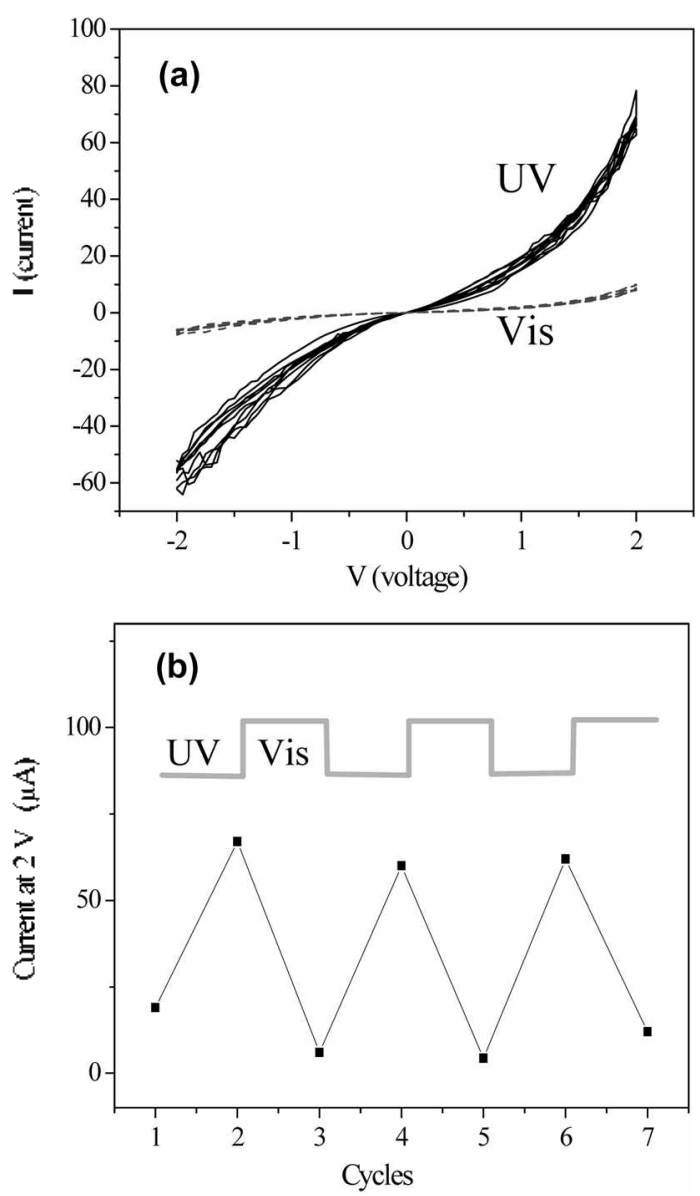

Figure 4. (a) I-V plot for the cell containing PS(90)/TBTFE(10) before (dashed line) and after (solid line) irradiation with $365 \mathrm{~nm}$ light within 5 cycles. (b) Photo-induced reversible switching of the current at $2 \mathrm{~V}$ by the altemative UV and vis (532 nm) light excitation.

$\mathrm{cm}^{2.31}$ The photo cell showed a color change by the UV and visible light exposure similar to that in the solution spectra.

The applied voltage dependence of the electric current is shown in Figure 4 . The I-V curve was stable over repeated cycles. particularly at the dark area. It is important to note that the slope of the I-V curve for the cell that contained TBTFE significantly increased when the cell was irradiated with UV light for $10 \mathrm{~min}$. The current at $2 \mathrm{~V}$ for the colored cell was much larger than that of the bleached cell. This demonstrates that the $\pi$-electron conjugation between the 
donor $T$ and the acceptor E group in TBTFE was extended. resulting in a higher current response than in the open form. in which such $\pi$-conjugation was linited. In particular, the donor-acceptor substituents could allow the electron transport between the molecules, as schematically shown below.

The conductivity was determined from the linear region of the $\mathrm{I}-\mathrm{V}$ plot as $5 \times 10^{-15}$ and $1.2 \times 10^{-8} \mathrm{~S} / \mathrm{cm}$ for the cell

were determined by the National Center for Inter-University Research Facilities. Column cluromatography was performed using silica gel (200-400 mesh, Merck). All reactions were monitored for completion using thin-layer chromatography (TLC). which was performed using a pre-coated silica gel plate (Merck $60 \mathrm{~F}_{245}$ ). and detection was perfomed with the aid of UV light. Melting points were measured on the Fisher-Jones melting point apparatus and uncorrected. The UV-Vis spectra were recorded for chloroform solutions with a Jasco V-530 UV/Vis spectrophotometer. Molar absorption coeffi-cients were experimentally determined from the absorbance change at different concentrations using Lambert-Beer's Law. The electrochemical properties were studied using cyclic voltammetry (CV) on a BAS $100 \mathrm{~B}$ electrochenical analyzer (BAS, Inc). The measurement was carried out in a $10-\mathrm{mL}$ methylene chloride solution that contained tetra-n-butylammonium perchlorate (TBAP. $0.1 \mathrm{M} / 0.34 \mathrm{~g}$ ) as a

containing $10 \mathrm{wt} \%$ of TBTFE, before and after UV irradiation, respectively. The $\mathrm{I}-\mathrm{V}$ curve upon irradiation of the cell with a visible light was overlapped with that of the dark state. Importantly the current change was reversible allowing conductivity modulation through altemative irradiation with UV and visible lights over several repeated cycles (Fig. 4b). The switching efficiency, as defined by the ratio of the conductivities of the cells irradiated with UV and visible lights. was 2.4 .

The conductivity of the colored cell containing 1 was $10^{-11}$ $\mathrm{S} / \mathrm{cml}^{31}$ The conductivity of the PS binder without diarylethene was lower than $10^{-12} \mathrm{~S} / \mathrm{cm}{ }^{3}$. This implies that the charge transport nust be facilitated in a donor-acceptor structure such as TBTFE that can push/pull the carrier during the transport between the molecules. Electrochemical switching through alternative UV/risible light irradiation of the film made of TBTFE could be applied in a photon-mode actuation. electrochemical and photochemical storage of information. and in photoelectrode patterning for biological and non-biological systems. ${ }^{31,33}$ Furthermore. conductivity switching from an organic photochromic film could be utilized to charge injection control at the metal/organic interface by light.

\section{Experimental Methodology}

General Methodology. Methylene clloride and toluene were distilled from phosphorus pentoxide prior to use and tetra-n-butylammonium perchlorate (TBAP) was purchased from TCI. The ${ }^{1} \mathrm{H}$ and ${ }^{13} \mathrm{C}$. NMR spectra were recorded as $300 \mathrm{MHz}$ and $75 \mathrm{MHz}$. respectively, in a $\mathrm{CDCl}_{3}$ solution that contained $\mathrm{Me}_{4} \mathrm{Si}$ as internal standard with Bruker. IR spectra were recorded on a Shimadzu 540 spectrophotometer in $\mathrm{KBr}$ or film on KBr plates. An elemental analysis was performed by the Korea Basic Science Center. The FAB mass spectra supporting electrolyte. Each of the photochromic compounds were dissolved under an argon atmosphere. The condition was composed of a three-electrode assembly equipped with a platinum working electrode, a platinum coil as the counter electrode, and an $\mathrm{Ag} / \mathrm{AgCl}$ electrode as the reference electrode. Measurements were examined in a glass cell at room temperature. The cell was measured before and after it was irradiated with UV light and after it was blenched with visible light. The scan rate was $200 \mathrm{mV} / \mathrm{sec}$ and the voltage range was $-1.5 \sim+1.5 \mathrm{~V}$. The current-voltage $(\mathrm{I}-\mathrm{V})$ properties were measured using Agilent E5272A 2-Channel (High-power and Medium-power) Source/Monitor Units of Agilent Technologies. The measurement range was -2.0 $\sim+2.0 \mathrm{~V}$. For the study of the I-V characterization. the mixture of TBTFE (10 wt \%) in polystyrene (Polysciences. Inc. $50.000 \mathrm{Mw}$ ) was dissolved in chloroform and 1.1.2.2tetrachloroethane. The solution was spin-coated on the ITO glass. Then the coated glass film was dried in an oven at 70 ${ }^{\circ} \mathrm{C}$ for more than $12 \mathrm{~h}$. and gold was evaporated at a higher temperature. The thickness of the photochromic material was $220 \mathrm{~nm}$ and of gold. $40 \mathrm{~nm}$. Before the glass film was coated the solution was exposed to light $(365 \mathrm{~nm} .0 .5 \mathrm{~mW})$ for 10 min. after which its properties were examined. After the film was bleached with light $(532 \mathrm{~nm}, 2.0 \mathrm{~mW})$. its current-voltage character was again investigated.

2-Tri-butylstannyl-3,4-ethylenedioxythiophene (TSn). To a solution of 3.4 -ethylenedioxythiophene $(4.50 \mathrm{~g} .320$ mmol) and $N, N, N^{\prime}, N^{\prime}$-tetramethy lethy lenediamine (TMEDA) (4.25 g. $370 \mathrm{mmol})$ in anhydrous diethyl ether $(100 \mathrm{~mL})$. a solution of $n$-butyllithium (12.7 mL. $320 \mathrm{mmol}, 2.5 \mathrm{M}$ in hexane) was slowly added using a șringe under an argon atmosphere at room temperature. The mixture was stirred at room temperature for $10 \mathrm{~min}$, and then refluxed for $30 \mathrm{~min}$. A pink. milk-like mixture was formed. The mixture was cooled to $-25^{\circ} \mathrm{C}$. and tributyltin chloride (10.33 g. 320 
mmol) was added slowly to it over $(\mathrm{h}$. The reaction mixture was warmed up to room temperature and stirred for $3 \mathrm{~h}$. After it was quenched with a saturated sodium chloride solution $(50 \mathrm{~mL})$. its organic layer was extracted with diethyl ether $(3 \times 30 \mathrm{~mL})$. dried over $\mathrm{MgSO}_{4}$. and filtered. Triethylamine $(10 \mathrm{~mL})$ was added to the filtrate. and the solvents were evaporated. The residue was purified using column chromatography with hexane on a pre-treated silica gel (washed silica gel with neat triethylamine. then hexane). The solvent was removed in a vacuum and the residue was further purified through vacuum distillation to produce a colorless liquid [yield $=68 \%:{ }^{1} \mathrm{H}$ NMR $\left(\mathrm{CDCl}_{3}, 300 \mathrm{MHz}\right)=$ $0.90(\mathrm{t} . J=7 \mathrm{~Hz}, 9 \mathrm{H}, \mathrm{Me}) .1 .10\left(\mathrm{~m} .6 \mathrm{H},-\mathrm{CH}_{2}\right) .1 .34(\mathrm{~m} .6$ H. - $\left.\mathrm{CH}_{2}-\right), 1.56\left(\mathrm{~m} .6 \mathrm{H},-\mathrm{SnCH}_{2}-\right), 4.15$ (m. $\left.4 \mathrm{H},-\mathrm{OCH}_{2}\right)$. and $6.57(\mathrm{~s}, \mathrm{I} \mathrm{H},-\mathrm{CH}-)]$.

1-(6-Acetyl-2-methyl-1-benzothiophen-3-yl)-2-(2'-methyl-1'-benzothiophen-3'-yl)hexafluorocyclopentene (BTFA). To a well-stirred methy lene chloride solution $(20 \mathrm{~mL})$ of 500 mg (1.1 munol) of 1,2-bis(2-methyl-1-benzothiophen-3yl)hexafluorocyclopentene (1) and $130 \mathrm{mg}(1.7 \mathrm{mmnol})$ of acetyl chloride was added $230 \mathrm{mg}$ of aluminum chloride over $\mathrm{l} h$ at room temperature. The solution was stirred for an additional $1 \mathrm{~h}$. To stop the reaction, dilute $\mathrm{HCl}$ was added. The reaction mixture was extracted with chloroform $(3 \times 30$ $\mathrm{mL})$. The organic layer was washed with water $(30 \mathrm{~mL})$. dried over $\mathrm{MgSO}_{4}$. filtered, and evaporated. The residue was purified by columu chromatography on silica gel using hexane/chloroform ( $1: 2)$ as the eluent to give BTFA (yield: $45 \%)$ : parallel(p):antiparallel $(\mathrm{ap})=40: 60 .{ }^{1} \mathrm{H} \mathrm{NMR}\left(\mathrm{CDCl}_{3}\right.$. $300 \mathrm{MHz}$ ) $\delta 2.21$ (s, 2H. apMe), 2.26 (s. $2 \mathrm{H}$. apMe), 2.48 (s, lH, pMe). 2.53 (s, lH. pMe). 2.57 (s, lH. apCOMe). 2.65 (s. $2 \mathrm{H}$, pCOMe) $7.18-7.70$ (m. 6H. $\mathrm{ArH}), 8.22(\mathrm{~s}, 0.4 \mathrm{H}$. apArH), 8.31 (s, 0.6H, pArH): ${ }^{13} \mathrm{C} \mathrm{NMR}\left(\mathrm{CDCl}_{3 .} .75 \mathrm{MHz}\right) \delta$ $15.2,15.5$. 26.8. 122.1. 122.2, 123.1, 123.4, 124.4. 124.5. 124.8. 133.1, 133.3, 141.6, 197.3.

1-(6-Carboxy-2-methyl-1-benzothiophen-3-yl)-2-(2'methyl-1'-benzothiophen-3'-yl)hexafluorocyclopentene (BTFC). The solution of BTFA $300 \mathrm{mg}(0.58 \mathrm{mmol})$ in 25 $\mathrm{mL}$ of dioxane was stirred and heated to $55^{\circ} \mathrm{C}$. A mixture of $5 \mathrm{~mL}$ of $12 \%$ sodium hypochlorite. $5 \mathrm{~mL}$ of water and $3.2 \mathrm{~g}$ of potassium hydroxide was added $1 \mathrm{~mL}$ at a time over 45 minutes. while heating to $80^{\circ} \mathrm{C}$ and kept at the temperature for $3 \mathrm{~h}$. Then aqueous sodium sulfite was added to decompose the excess sodium hypochlorite. The aqueous layer was acidified with $6 \mathrm{M}$ hydrochloric acid to precipitate pale green crystalline acid The solid was filtered to obtain pale green cry'stal (BTFC) (vield: $80 \%$ ): $\mathrm{mp}=152-156^{\circ} \mathrm{C}$ (decompose or decarboxylate. but have no sharp melting point): parallel(p):antiparallel(ap) $=35: 65:{ }^{1} \mathrm{H}$ NMR $\left(\mathrm{CDCl}_{3}, 300\right.$ MHz) $\delta 2.13$ (s. 2H. apMe), 2.18 (s. 2H. apMe), 2.45 (s, 1H. pMe), $2.53(\mathrm{~s}, 1 \mathrm{H}, \mathrm{pMe}), 7.08-7.70(\mathrm{~m}, 6 \mathrm{H}, \mathrm{ArH}), 8.36(\mathrm{~s}$. $0.4 \mathrm{H}$. apArH). 8.44 (s. 0.6H. pArH) ${ }^{13} \mathrm{C} \mathrm{NMR}\left(\mathrm{CDCl}_{3}, 75\right.$ MHz) $\delta 15.0,15.4,118.8 .119 .2,121.8 .122 .1,124.5,124.7$. 125.9. 137.9, 138.2,142.0,142.2,142.7, 171.7.

1-(6-Carboxy-2-methyl-1-benzothiophen-3-yl)-2-(6'iodo-2'-methyl-1'-benzothiophen-3'-yl)hexafluorocyclopentene (IBTFC). Iodine $75 \mathrm{mg}(0.29 \mathrm{mmol})$ and $\mathrm{H}_{5} \mathrm{IO}_{6} 3 \mathrm{I}$ $\mathrm{g}(0.14 \mathrm{mmol})$ was added to a stirred solution of BTFC 200 $\mathrm{mg}(0.39 \mathrm{mmol})$ in acetic acid $(30 \mathrm{~mL})$. sulfuric acid $(\mathrm{lmL})$. and water $(1.5 \mathrm{~mL})$. and the mixture was stirred for $3 \mathrm{~h}$ at 70 ${ }^{\circ} \mathrm{C}$ in the open air. The reaction mixture was poured into 500 $\mathrm{mL}$ of ice water. The pale pink heavy precipitate formed. and filtered to obtain pale pink crystal (IBTFC) (yield $73 \%$ ): $\mathrm{mp}=138-144^{\circ} \mathrm{C}$ (decompose or decarboxylate, but have no sharp melting point): parallel(p):antiparallel(ap) $=$ 40:60; ${ }^{1} \mathrm{H}$ NMR (CDCl, $\left.300 \mathrm{MHz}\right) \delta 2.20(\mathrm{~s}, 2 \mathrm{H}$, apMe), 2.25 (s. $2 \mathrm{H}$. apMe). 2.43 (s. IH. pMe). 2.48 (s. IH. pMe), 7.35-8.13 (m. 6H. ArH). 8.42 (s, 0.4H. apArH), 8.50 (s, $0.6 \mathrm{H}, \mathrm{pArH}) ;{ }^{13} \mathrm{C} \mathrm{NMR}(\mathrm{CDCl}, 75 \mathrm{MHz}) \delta 15.1 .15 .5 .89 .1$, 118.8, 119.1. 121.5, 121.7. 123.1, 123.4. 124.2, 125.7. 125.9, 126.8, 130.7, 133.5. 137.4. 138.0, 140.0, 140.1. 141.4. 146.5, 146.9. 166.2.

1-[6-(Ethyloxy)carbonyl-2-methy]-1-benzothiophen-3yl]-2-(6'-iodo-2'-methyl-1'-benzothiophen-3'-yl)hexafluorocyclopentene (IBTFE). The mixture of IBTFC ( 100 mg. $0.15 \mathrm{mmol}$ ), $20 \mathrm{~mL}$ absolute ethanol and $1 \mathrm{~mL}$ was refluxed for $6 \mathrm{~h}$. Cooling to the room temperature and neutralized with an aqueous solution of $\mathrm{NaHCO}_{3}$. The mixture was extracted with methy lene chloride $(3 \times 30 \mathrm{~mL})$, dried over $\mathrm{MgSO}_{4}$, filtered. and evaporated. The residue was purified by column chromatograply on silica gel using hexane/etlyy acetate (10:1) as the eluent to give IBTFE (yield: $65 \%$ ); parallel(p):antiparallel(ap) $=35: 65:{ }^{1} \mathrm{H}$ NMR $\left(\mathrm{CDCl}_{3} .300 \mathrm{MHz}\right) \delta 1.39$ (t. $\left.J=7 \mathrm{~Hz}, 3 \mathrm{H} . \mathrm{Et}\right), 2.18$ (s. $2 \mathrm{H}$, apMe). 2.25 (s. $2 \mathrm{H}$ apMe), 2.47 (s. $1 \mathrm{H}$. pMe). $2.5 \mathrm{l}$ (s, $1 \mathrm{H}$, pMe), 4.40 (q. $J=7 \mathrm{~Hz} .2 \mathrm{H}, \mathrm{Et}$ ). $7.22-8.05$ (m. 6H, ArH), 8.36 (s. $0.4 \mathrm{H}, \mathrm{apArH}), 8.43$ (s, 0.6H. pArH); ${ }^{13} \mathrm{C}$ NMR $\left(\mathrm{CDCl}_{3} .75 \mathrm{MHz}\right) \delta 15.1,15.5,29.7,61.2 .89 .1,118.8$. $119.1,121.5 .121 .7 .123 .1,123.4 .124 .2,125.7 .125 .9$. $126.8,130.7,133.5 .137 .4 .138 .0,140.0,140.1 .141 .4$. 146.5, 146.9. 166.2.

1-[6-(3',4'-Ethylenedioxy)thienyl]-2-methyl-1-benzothiophen-3-yl]-2-(6'-(ethyloxy)carbonyl-2'-methyl-1'benzothiophen-3'-yl)hexafluorocyclopentene (TBTFE). Under argon atmosphere. 2-tributylstannyl-3.4-ethylenedioxy thiophene $(100 \mathrm{mg} .0 .150 \mathrm{mmol})$ and IBTFE $(65 \mathrm{mg}$. $0.150 \mathrm{~mm} o l$ ) were dissolved in $30 \mathrm{~mL}$ of toluene. To this was added a catalytic amount of dichlorobis(triphenylphosphine)palladium(II) $\left(\mathrm{PdCl}_{2}\left(\mathrm{PPh}_{3}\right)_{2}\right)^{8} \mathrm{mg}(0.0105$ mumol) and the mixture was refluxed for $24 \mathrm{~h}$. During the reaction, the color changed from yellow to black as $\mathrm{Pd}^{\text {" was }}$ formed. After cooling, the reaction mixture was poured into saturated sodium clloride solution $(50 \mathrm{~mL})$. Benzene (20 $\mathrm{mL}$ ) was added. The organic layer was extracted with benzene $(3 \times 30 \mathrm{~mL})$. dried over $\mathrm{MgSO}_{4}$, filtered. and evaporated. The residue was purified by column chromatograply on silica gel using hexane/ethyl acetate (5:1) as the eluent to give TBTFE (yield: $53 \%$ ): parallel(p): antiparallel(ap) $=35$ : $6{ }^{1} \mathrm{H}$ NMR (CDCl $\left.3.300 \mathrm{MHz}\right) \delta 1.3$ (t. $J=7 \mathrm{~Hz} .3 \mathrm{H} . \mathrm{Et}$ ), 2.15 (s, 2H, apMe), 2.24 (s. $2 \mathrm{H}$. apMe). 2.44 (s, $1 \mathrm{H}, \mathrm{pMe}$ ), 2.50 (s. $1 \mathrm{H}, \mathrm{pMe}), 4.24$ (m, $\left.2 \mathrm{H},-\mathrm{OCH}_{2}\right), 4.30(\mathrm{~m}, 2 \mathrm{H}$, $\left.-\mathrm{OCH}_{2}\right) .4 .40$ (q. $\left.J=7 \mathrm{~Hz}, 2 \mathrm{H}, \mathrm{Et}\right) .6 .30(\mathrm{~s}, 1 \mathrm{H},-\mathrm{CH}-), 7.47 \cdot$ 8.06 (m, 6H, ArH), 8.30 (s. $0.4 \mathrm{H}, \mathrm{apArH}), 8.430$ (s. $0.6 \mathrm{H}$, $\mathrm{pArH}): \mathbf{M S} m z 680\left(\mathrm{M}^{-}\right)$. 


\section{Conclusions}

A new diarylethene, with 3,4-ethylenediosythiophene (T) and carboethosy (E) group as the electron donor and acceptor group. respectively, was synthesized to achieve photochromic and photo-induced electrochemical switching with UV and visible light irradiation. The donor-acceptor structured TBTFE showed a significant shift in electronic transition in its closed form, which resulted in spectral and redox potential changes. The closed form of TBTFE. generated through UV exposure. showed a higher current-tovoltage response. which resulted in a higher conductivity than that of the open form. Thus. electronic switching of the cell containing TBTFE was possible with the alternative UV and visible light excitation. Such a switching from an organic photocluromic film could be utilized to injection control at the metal/organic interface by light.

Acknowledgments. This work was conducted through a financial grant from the Nanoteclnology Development Program of the Ministry of Science and Technology (MOST). of Korea and Seoul R\&DB program

Supporting Information. The spectra (SFigl-14) for the characterization of compounds are available upon request from the correspondence author $(02-2123-5752$. eunkim $a$; yonsei.ac.kr).

\section{References}

1. (a) Brown, G. H. Photochomism Wiler-Interscience: New York. 1971. (b) Dürr. H.: Bouas-Laurent. H. Photochrontism: Holecules and Svstents: Elsevier: Amsterdam. 1990. (c) Irie. M.: Uchida. K. Bull. Chem. Soc. Jph. 1998.71.985

2. Tsivgoulis. G. M.: Lehn. T.M. Ad. Mater 1997.9.627.

3. (a) Gilat. S. L.: Kawai, S. H.; Lehn, J.M. J. Chem. Soc. Chem. Conmm. 1994 1011. (b) Kawai. S. H. Lelm. J.-M. Chem. Em J. 1995. 1.275

4. (a) Kawai. S. H.: Gilat. S. L.: Lehn. J-M. J. Chent. Soc. Chem. Commun. 1993. 1439. (b) Gilat. S. L.: Kawai. S. H.: Lehn. J.-M. Chem. Ew J. 1995, 1, 285

5. (a) Tsivgoulis, G. M. Lehn. I.-M. Angew. (Chem. 1995, 107, 1188 and Angew. Chem. Int Ed. Engl. 1995, 34. 1119 (b) Tsivgoulis, G. M.: Lehn. J-M. Chen. Eur. J. 1996. 2. 1399.

6. Fernándes-Acebes. A.: Lehn. J-M. Att: Hater. 1998. 10. 1519

7. Irie. M.: Sakemura. M.: Okinaka. M.: Uchida. K. J. Org. Chemt. $1995,60,8305$

8. (a) Kim. E.: Choi. Y.-K.: Lee. M.-H. Macromolecules 1999. 32. 4855. (b) Kim. M.S.: Marlyanna. H; Kawai. T; Irie. M. Chem. Mater. 2003. 15. 4539. (c) Kim. J.: Song. K.-B.: Park. K.-H.: Lee.
H. W.: Kim. E. Japanese J. Appl. Ph.s. 2002, H. 5222. (d) Cho. H.: Kim. E. Macrontelectes 2002. 35. 8684. (e) Cho. S. Y: Yoo. M.: Shin. H.W: Ahr1. K.-H.: Kim. Y.-R: Kim. E. Optical Materials 2003. 21. 279. (f) Jeong. Y.C.: Yang. S. I.: Aln, K.-H. Kim. E. Chem. Comm 2005. 19. 2503.

9. (a) Kawai. T.: Kunitake. T. Chem. Lett 1999.905. (b) Tanio. N.: Irie. M. Jpn. J. Appl 1994. 34. 1550. (c) Kawai. T.: Nakashima. Y.: Irie. M. Ath: Mtater. 2005. 17. 309 .

10. (a) Ebisawa. F.: Hoshino. M.: Sukegawa. K. Appl. Plns. Lett. 1994. 65, 2919. (b) Kang, J.-W.: Kim. J.-S.: Lee, C.-M.: Kim, E: Kim. J.J. Electronic Letters 2000. 36, 1641. (c) Kang, J. W. Kim. J.-S: Lee. C.-M.: Kim. E.: Kim. J.-J. Appl. Phys. Lett. 2002. 80. 1710 .

11. (a) Lee. H. W.: Kim. E. Mol. Cnst. Liq. Chst. 2005. 431.581. (b) Choi. H.: Lee. H. W.: Kang. Y.: Kim. E.: Kang. S. O.: Ko. I. J. Org. Chem. 2005. 70,8291

12. Kim. M.: Kim, K; Kim. E. J. Kor: Soc, Imaging Sci. Techlol. 2005. 11,119

13. (a) Irie. M.: Molvi. M. J. Org. Chem. 1988. 53. 803, (b) Uchida. K.: Nakayama. M.: Irie. M. Bull. Chent Sax. Jph. 1990. 63. 1311.

14. Nakayama. M.: Hayashi. K.: Irie. M. J. Ong. Chent 1990. 55.2592.

15. Nakayama. M.; Hayashi. K.: Ine, M. Bull. Chem. Soc. Jpn. 1991. 64.789 .

16. Irie, M. Chem. Rev 2000, 100, 1685 .

17. Irie. M.: Uchida. K. Bull. Chen. Soc. Jpn. 1998. 71.985.

18. Hanazawa. M.: Sumiya. R.: Horikawa. Y.: Irie. M. J. Chem. Soc. Chent Conmum. 1992. 206

19. Irie, M. Aol Cryst Liq. Coyst 1993. 227, 263.

20. Sonmez. G; Meng. H; Zhang. Q; Wudl, F. Adr Funct. Hater. 2003. 13,726

21. (a) Gilat. S. L.: Kawai. S. H.: Lehn. T.M. Chem. Ent J. 1995. 1. 275. (b) Gilat. S. L.: Kawai. S. H.: Lehn. J.-M. J. Chem. Soc. Chent Conmum. 1993. 1439.

22. (a) Mejiritski. A.: Polvkarpoy. A. Y.: Sarker. A. M.: Neckkers, D C. J. Photochem. Photobiol 1997, 108, 289. (b) Kwon. D.-H: Shin, H.-W.: Kim, E.: Boo, D. W: Kim. Y.-R. Chem. Phrs. Lett 2000. 328. 234.

23. Kim. E.: Kim. M.: Kim. K. Tetrahedron 2006. 62.6814.

24. Irie. M.: Eriguchi. T.: Takada. T.: Uchida. K. Tetrahedron 1997. 53.214.

25. Matsuda, K.: Irie. M. J. Am. Chem Soc, 2000, 122,7195.

26. Casado. J.: Pappenfus, T. M.; Miller. L. L.; Mann K. R.: Orti. E. P.: Viruela. M.: Pou-Amerigo. R.: Hemandez. V: Lopez-Navarrete. J. T. J. Ant Chem. Soc. 2003. 125. 2524.

27. Pappenfus. T. M.: Raff. T. D.: Hulkinent. E. T.: Bumney. J. R.: Casado, J.: Drew, S. M.: Miller, L. L.: Mann, K. R. J. Org. Chem. 2003. 67,6015 .

28. Li. G.: Kobmehl, G.; Welzel, H.-P: Plieth, W: Zhu. H. M facromol. Chent Phis. 1998. 199. 2737.

29. Peters. A.: Branda. N. R. J. Ant Chent. Soc. 2003. 125. 3404

30. Bender. T. P.: Graham. T. F.: Duff. J. M. Chent. Hater. 2001. 13. 4105 .

31. Kim. E.: Lee. H. J. Hater: Chom 2006. 16. 1384.

32. Baron, R.: Onoprivento, A.: Katz. E.: Lioubashevshi, O.: Willner. I.: Wang. S.: Tian1. H. Chem. Commm. 2006. 2147. 